\title{
Is Laparoscopic Appendectomy Superior to Open Appendectomy?
}

\author{
MOHAMED M. AHMED SAKRAN, M.Sc.; AMER H.E. BARRAWY, M.D. and \\ HAMED A. ABDEL HAMEED ELBADWY, M.D.
}

The Department of General Surgery, Faculty of Medicine, Al-Azhar University

\begin{abstract}
Background: The most common emergency for surgery in the population is acute appendicitis. Though laparoscopic appendectomy is widely performed today, the advantages of laparoscopic versus open appendectomy remain under controversy.

Aim of Study: To determine whether Laparoscopic Appendectomy (LA) is better than thetraditional Open Appendectomy (OA).

Patients and Methods: It is a prospective study, involving 150 patients with acute appendicitis. All patients undertook abdominoal and pelvic ultrasonography, to exclude any concomitant gynecological finding and other cause for right iliac fossa pain.

The patients were admitted to in Al-Zahraa University Hospital and Kobry El-Koba Military Hospital during the period from November 2017 to November 2019. Operational time, post-operative pain, first bowel movement, hospital stay, early work return and post-operative complications were compared in patients with open versus laparoscopic appendectomy.

Results: OA and LA were performed in 150 patients ( 75 patients for each procedure). The laparoscopic technique gave less length of hospital stay ( $p=0.025)$, better in operative time, short hospital stay, low visual pain analogue range, first bowel motion recorded and early return to normal activity $(p<0.01)$ less intraoperative and post-operative complications $6.7 \%$ of all patients had complications post-operatively all in open group.

Conclusion: The advantage of laparoscopic appendectomy is decreased pain following surgery, a short hospitalization, and an early return to work. Laparoscopic appendectomy should be recommended for acute appendicitis as an effective and safe procedure.
\end{abstract}

Key Words: Laparoscopic Appendectomy-Appendectomy.

\section{Introduction}

THE benefit of laparoscopic appendectomy is reduced pain following surgery, a brief hospitali-

Correspondence to: Dr. Mohamed M. Ahmed Sakran, The Department of General Surgery, Faculty of Medicine, Al-Azhar University zation, and an early return to work. Laparoscopic appendectomy should be recommended for acute appendicitis as an effective and safe procedure [1]

Open appendectomy is still the normal procedure for acute appendicitis that, because of its beneficial effectiveness and protection for 100 years, remains largely unchanged. Also if laparoscopic procedure has been possible for a long time, and standardized laparoscopic cholecystectomy, it is not clear if the most suitable choice for acute appendicitis is Open Appendectomy (OA). Or laparoscopic appendectomy (OA) [2] .

The advantage of laparoscopic efficiency, providing excellent peritoneal cavity visualization. In women where the laparoscopic approach can allow ovarian or uterine abnormalities to be identified, the laparoscopy also offers optimum show in patients who are obese and the preferred approach [3].

The new form, however, was only partly adopted because the advantages of laparoscopic appendectomy, for example, were not as obvious as in laparoscopic cholecystectomy. Some studies have proposed that the laparoscopic appendectomy is preferable to an initial appendectomy for quicker and less painful recovery and less post-operative complications and improved cosmetic results [4]

Many advantages of laparoscopic surgery compared to open the appendectomy have been reported. It needs a small incision and it gives good visualization; it also provides better access to abdominal organs and rapid post-operative recovery. Yet Randomized controlled trial meta-analyzes found that this approach was better than open appendectomy. It was shown that LA gave more incidence of intra-abdominal abscess compared to OA [17]. 
In open appendectomy, the most common complication was wound infection, while laparoscopic procedures were the most common complication in intraabdominal abscess. Recent studies have shown a trend towards more laparoscopic intraabdominal infection, with intra-abdominal abscess being more frequent, particularly in complex cases of appendicitis [5].

In several places around the world, laparoscopic surgery has been approved. It proved to be a feasible and effective technique in many studies and metaanalyzes with several clinical advantages including shorter post-operative ileus, lower wound frequency, less post-operative discomfort, decreased hospital stay and a fast return to normal activities. As the chance of surgical complications was minimized by Laparoscopic Appendectomy (LA) [6]

\section{Patients and Methods}

This was a prospective study which involved 150 consecutive patients with acute appendicitis. All patients undertook upper abdomino-pelvic ultrasonography, to exclude any concomitant gynecological finding and other cause for right iliac fossa pain.

The patients were admitted to in Al-Zahraa University Hospital and Kobry El-Koba Military Hospital, during the period from November 2017 to November 2019. Ethical approval statement was obtained according the committee of ethics. Data were collected from the written permit, and clarification was given for possible problems that may arise during the perioperative period.

The patients were correspondingly randomized in two groups.

Group A: Including 75 patients for whom LA was done.

Group B: Including 75 for whom OA was done.

- All patients were admitted to the appropriate ward via the A \& E, underwent surgery as emergency cases.

- Inclusion criteria: citis.

Patients with clinical picture of acute appendi-

\section{- Exclusion criteria:}

Other causes of acute lower abdominal pain and patients with respiratory problems or with cardiac disease affecting cardiac functions.

- Careful history was obtained from the patients on the basis of thorough clinical evaluation:
General and abdominal evaluations were performed lower right quadrant tenderness was typically present. Any patient with an acute appendicitis score of 7 or more was administered.

- Routine lab investigations such as full blood count, liver function tests, random blood sugar, serum urea, creatinine and INR.

- Plain chest X-ray was done in all cases.

- Investigations in the form of abdomino-pelvic ultrasound to assess the tenderness on probing in right iliac fossa and presence of right iliac fossa or pelvic collection and to exclude any concomitant gynecological finding e.g. tubal pregnancy or ovarian cyst. Also, to exclude any other cause for right iliac fossa pain, e.g. ileocecal intussusception.

- Consent from the patients about the operation and its complications was taken. All surgical procedures were carried out under general anesthesia and all surgeries were done by a senior surgeon.

- Antibiotic prophylaxis.

In the prevention of surgical and intra-abscesses, the administration of prophylactic antibiotics 3 is critical. Enteric gram-negative bacilli, anaerobe and enterococcus are the most common flora in this disease (E.coli, Kleibsiella, Proteus \& Bacteroides).

Under general anesthesia from a routine $\mathrm{Mc}$ Burney incision in OA, the mesoappendix was divided between clamps, connected by an absorbent suture of 2-0, and two hemostatic clamps were placed on the base of the appendix itself. The closest clamp to the caecum was taken off, and the appendix was crushed on that site. The appendix was twice bundled using two heavy, absorbable sutures, which were then divided proximally to the second bandage.

Under general anesthesia in LA; after skin preparation, a needle or open technique was used to create a pneumoperitoneum, the port placement of $10 \mathrm{~mm}$ above the umbilicus for the laparoscope is placed. When the versus needle is used to build up pneumoperitoneum, we insert the abdomen $10 \mathrm{~mm}$ and two additional ports, once the carbon dioxide has been inflated to an intra-abdominal pressure of $14 \mathrm{mmHg}$. Also in the left fossa a $5 \mathrm{~mm}$ port was mounted. In the right hypochondrium regionan additional $5 \mathrm{~mm}$ port was added.

The positioning of this last port will allow a bowel grasper inserted via the lower left quadrant 
port. On the country, too far lateral positioning makes the lower left quadrant port troublesome as instruments may not reach the appendix. Identifying the appendix is used to visualize the right lower quadrant.

As laparoscopy will either confirm the diagnosis or lead to an alternate diagnosis, diagnostic laparoscopy is recommended prior to proceeding to the appendectomy.

Mesoappendix coagulation has been achieved by using the diathermy or harmonic or ligasure to extract the mesoappendix. Any connective or adipose tissue around the appendix should be removed, leaving the appendix just attached to the cecum base. We protect in an extracorporeal way the base of the appendix by pushing a knot pusher across the port at the right hand side with two successive links of Vicryl 2/0.

The appendix is inserted in an extraction sac from the abdomen. Throughout this stage, it is vital that feculent contents are not spilled, and that the appendix does not touch the wound during the extraction process, as this leads to higher intraabdominal and wound infections. The appendix is removed through the umbilical tube. This can be achieved by moving the laparoscope to the suprapubic position and using a claw grasper to grab the endobag via the umbilical site.

We conducted a prospective study comparing differences between patients who underwent LA and OA, as regard to: Operating room time, intraoperative events and complication, drain insertion, post-operative complications, time of oral intake, and length of hospital stay.

All thefollowing operative details were recorded:

1- Operative time by minutes from skin incision to wound closure.

2- Intraoperative problems and transition into opening procedure,

3- Post-operative complications, morbidity including infection with the wound, general operating complications, collecting intraperitoneally, postoperative discomfort and time required to return to work.

4- Duration of stay at hospital.

5- Visual analog score for post-operative pain, VAS is a line, $10 \mathrm{~cm}$ long. The ends of the line reflecting the limits of pain that a patient can experience from an external stimulation, i.e. at one end: No pain, while at the other end most intense pain indicates. In the first 24 hours, patients were advised to put a mark on the $10 \mathrm{~cm}$ line showing the severity of post-operative pain.

\section{Statistical analysis:}

Recorded data were analyzed using the statistical package for social sciences, version 20.0 (SPSS Inc., Chicago, Illinois, USA). Quantitative data were expressed as mean \pm Standard Deviation (SD). Qualitative data were expressed as frequency and percentage. So,

\section{The following tests were done:}

-Independent-samples $t$-test of significance was used when comparing between two means.

- Mann Whitney U-test: For two-group comparisons in non-parametric data.

- Chi-square $\left(\chi^{2}\right)$ test of significance was used in order to compare proportions between qualitative parameters.

- The confidence interval was set to $95 \%$ and the margin of error accepted was set to $5 \%$. So, the $p$-value was considered significant as the following:

- Probability ( $p$-value).

- $p$-value $<0.05$ was considered significant.

- $p$-value <0.001 was considered as highly significant.

- $p$-value $>0.05$ was considered insignificant.

\section{Results}

Table (1) indicates highly statistically significant decreased mean in the lap appendectomy group in a comparison to open appendectomy group as regards operative time (minutes).

Table (2) presents highly statistically significant decrease mean was in the lap appendectomy group in a comparison to the open appendectomy group regarding the hospital stay (days).

Table (3) declares highly statistically significant decrease median in the lap appendectomy group in comparison to open appendectomy group according to pain analogue scale.

Table (4) indicates higher complications postoperatively in an open appendectomy group in a comparison to lap appendectomy group.

Table (5) indicates highly statistically significant decrease mean in the lap appendectomy group in a comparison to open appendectomy group according to returning towork and normal activity (days). 
Table (1): Comparison between open appendectomy and lap appendectomy according to operative time (minutes).

\begin{tabular}{lllll}
\hline $\begin{array}{l}\text { Operative } \\
\text { time } \\
(\text { minutes })\end{array}$ & $\begin{array}{c}\text { Open } \\
\text { appendectomy } \\
(\mathrm{n}=75)\end{array}$ & $\begin{array}{c}\text { Lap } \\
\text { appendectomy } \\
(\mathrm{n}=75)\end{array}$ & $\begin{array}{c}t \text { - } \\
\text { test }\end{array}$ & $\begin{array}{c}p- \\
\text { value }\end{array}$ \\
\hline $\begin{array}{l}\text { Mean } \pm \mathrm{SD} \\
\text { Range }\end{array}$ & $\begin{array}{l}40.39 \pm 6.34 \\
30-60\end{array}$ & $\begin{array}{l}29.47 \pm 6.39 \\
19 .-60\end{array}$ & 11.258 & $<0.001 * *$ \\
\hline
\end{tabular}

$t$-independent sample $t$-test.

$* *$ : $p$-value $<0.001 \mathrm{HS}$.

Table (2): Comparison between open appendectomy and lap appendectomy according to hospital stay (days).

\begin{tabular}{lllll}
\hline $\begin{array}{l}\text { Hospital } \\
\text { stay } \\
\text { (days) }\end{array}$ & $\begin{array}{c}\text { Open } \\
\text { appendectomy } \\
(\mathrm{n}=75)\end{array}$ & $\begin{array}{c}\text { Lap } \\
\text { appendectomy } \\
(\mathrm{n}=75)\end{array}$ & $\begin{array}{c}t \text { - } \\
\text { test }\end{array}$ & $\begin{array}{c}p^{-} \\
\text {value }\end{array}$ \\
\hline $\begin{array}{l}\text { Mean } \pm \mathrm{SD} \\
\text { Range }\end{array}$ & $\begin{array}{l}2.89 \pm 0.56 \\
2-4\end{array}$ & $\begin{array}{l}1.99 \pm 0.56 \\
1-3\end{array}$ & 8.895 & $<0.001^{* *}$ \\
\hline
\end{tabular}

$t$-independent sample $t$-test.

**: $p$-value <0.001 HS.

Table (3): Comparison between open appendectomy and lap appendectomy according to pain analogue scale.

\begin{tabular}{lcccc}
\hline $\begin{array}{l}\text { Pain analogue } \\
\text { scale }\end{array}$ & $\begin{array}{c}\text { Open } \\
\text { appendectomy } \\
(\mathrm{n}=75)\end{array}$ & $\begin{array}{c}\text { Lap } \\
\text { appendectomy } \\
(\mathrm{n}=75)\end{array}$ & Z-test & $p$-value \\
\hline Median (IQR) & $7(7-7)$ & $5(5-7)$ & 7.919 & $<0.001^{* *}$ \\
Range & $6-9$ & $4-7$ & & \\
\hline
\end{tabular}

Data are expressed median and Interquartile Range (IQR).

Z-Mann-Whitney test.

$* *: p$-value <0.001 HS.

Table (4): Comparison between open appendectomy and lap appendectomy according to post-operative complications.

\begin{tabular}{|c|c|c|c|c|}
\hline $\begin{array}{l}\text { Post-operative } \\
\text { complications }\end{array}$ & $\begin{array}{c}\text { Open } \\
\text { appendectomy } \\
(n=75)\end{array}$ & $\begin{array}{c}\text { Lap } \\
\text { appendectomy } \\
(\mathrm{n}=75)\end{array}$ & $x^{2}$ & $p$-value \\
\hline $\begin{array}{l}\text { - Wound site } \\
\text { infection }\end{array}$ & $9(12.0 \%)$ & $1(1.3 \%)$ & 5.300 & $0.021 *$ \\
\hline - Port site hernia & $0(0.0 \%)$ & $0(0.0 \%)$ & 0.000 & 1.000 \\
\hline $\begin{array}{l}\text { - Intra abdominal } \\
\text { abscess }\end{array}$ & $0(0.0 \%)$ & $0(0.0 \%)$ & 0.000 & 1.000 \\
\hline - Fever & $11(14.7 \%)$ & $1(1.3 \%)$ & 7.419 & $0.007 *$ \\
\hline - Serroma & $8 \quad(10.7 \%)$ & $0(0.0 \%)$ & 6.497 & $0.011 *$ \\
\hline $\begin{array}{l}\text { - All positivbe } \\
\text { complications }\end{array}$ & $28(37.3 \%)$ & $1(1.3 \%)$ & 28.935 & $<0.001 * *$ \\
\hline $\begin{array}{l}\chi^{2}: \text { Chi-square te } \\
p \text {-value }>0.05 \mathrm{NS}\end{array}$ & & $\begin{array}{l}*: p \text {-value } \\
* *: p \text {-value }\end{array}$ & 0.05 & \\
\hline
\end{tabular}

Table (5): Comparison between open appendectomy and lap appendectomy according to return to normal activity and work (days).

\begin{tabular}{lcccc}
\hline $\begin{array}{l}\text { Return to normal } \\
\begin{array}{l}\text { activity and } \\
\text { work (days) }\end{array}\end{array}$ & $\begin{array}{c}\text { Open } \\
\text { appendectomy } \\
(\mathrm{n}=75)\end{array}$ & $\begin{array}{c}\text { Lap } \\
\text { appendectomy } \\
(\mathrm{n}=75)\end{array}$ & $\begin{array}{c}t- \\
\text { test }\end{array}$ & $\begin{array}{c}p \text { - } \\
\text { value }\end{array}$ \\
\hline Mean \pm SD & $27.20 \pm 5.61$ & $\begin{array}{l}18.36 \pm 3.47 \\
13-25\end{array}$ & 44.922 & $<0.001 * *$ \\
Range & $18-35$ & $* *: p$-value $<0.001 \mathrm{HS}$.
\end{tabular}

\section{Discussion}

For more than a century, the gold standard remained unchanged for treating acute appendicitis. Semm, a German surgeon, first described Laparoscopic Appendectomy (LA) in 1983, which has since become popular at the expense of open appendectomy [7].

Over the last two decades, the most procedures have changed significantly from open to minimally invasive. Although classic open appendectomy is simple and effective, it has some drawbacks like wound infection with painful, and delayed recovery. Another option that seems to have benefits over the open approach is laparoscopic appendectomy because it uses smaller access incisions that allow for clearer and wider vision of a camera. One should always think of laparoscopic operation and be open to each other as complementary. The benefits mentioned in several studies are shorter spent in hospital, lower death rates, faster return to work and lower hospital costs. However, there is still a controversy regarding these benefits and laparoscopic appendectomy has not totally replaced the open method [8].

Our study showed that operating time in open appendectomy was 40.39 minutes and the mean operating time in lap appendectomy was 29.47 minutes. Other studies explained that longer laparoscopic surgery was due to additional gas insufflations in LA, the entry of trocars and diagnostic confirmation as well as techniques that would be more complicated when acute appendicitis is complicated worldwide [9].

In another study, that reported open vs. laparoscopic appendectomy, the laparoscopic group reported a longer operation time (87 versus 65 minutes), but fewer parenteral oral analgesics were required and full activities were returned considerably faster (14 vs. 25 days) [10]

We have noticed no difference in the duration of our cohort in another study which shows a longer period of operations for LA compared to OA in perforated appendicitis. Increased experience with LA in a surgeon could explain that perforated appendicitis has no significant surgical time, as reports from previous studies [11].

Our study showed a mean hospitalization (days) for open appendectomy of 2,89, while the average hospitalization (days) for lap appendectomy was 1,99. Reduced hospitalization, reduced post-op. morbidity and less than open-cut care were correlated with laparoscope approach. Despite the 
obvious benefits described, LA's benefit continues to be discussed due to concerns about possible longer operational time, higher post-op intraabdominal abscesses, as well as increased costs in comparison to OA. Because of this, the open approach still seems to be widely used in clinical practice [7].

In an Italian study, out of 593 patients with acute appendicitis, 310 were appendectomy-open and 283 were appendectomy-laparoscopic. In laparoscopic group, shorter hospital stays (mean 1.4 \pm 0.6 days) were significantly shorter in the laparoscopic group ( $p=0.015$ ) where the patient's laparoscopically handled premature bowel movements resulted in earlier hospital feeding and discharge. The results of our studies are consistent with several studies that show that laparoscopic stays are significantly short [12].

In our study range of pain analogue scale in open appendectomy was 6 to $9($ median $=7)$ and the range of pain analogue scale in lap appendectomy was 4 to 7 (median=5), subjectively as well as critically, analgesic tabulation measured pain in another study. During the early 48 hours post lap appendectomy, in another study that has recorded linear analogue pain values in 135 patients who had been randomly to a particular procedure and had very little pain in the lap group relative to the opening. Those who had lap appendectomy had more pain, but their extent was less [5]

In another study, the criteria for analgesics and the VAS scores after surgery can be quantitatively assessed. Nevertheless, the degree and relief of pain in the LA group was shown to be a viable alternative to OA, especially in women and the obese, through different forms of analgesics and routes of administration. Latest research indicates that a laparoscopic procedure has a lower wound infection risk, a smoother return to work and improved cosmetic results for the patient [13].

In our study, post-operatively problematic patients with open appendectomy were 9 with woundsite infection, 11 with fever, 8 with seroma and 28 with all positive complications. In the lap appendectomy group these were only 1 with wound-site infection, 1 with fever with and 1 with allpositive complications. The study indicates that the period of hospital hospitalizations for patients with LAP was 3,49 days $(p=0,0022)$. The findings of Wei et al.'s and other recent cohort studies are comparable [14]

In another study, post-operative risk such as vomiting among groups of laparoscopy was less 2
(8\%) compared to 7 (28\%) open group compared with fever in group laparoscopy $4(16 \%)$ compared to $1(4 \%)$ in the open group. In the laparoscopic community, post-operative Ileus was lower at $17.3 \mathrm{hr}$ and $30.8 \mathrm{hr}$ at the open group [15]

Anotherstudy reported a significant reduction in the wound infection rate after laparoscopic appendectomy, which was consistent with the lower perforation rate and other published studies. In a meta analyzed randomized controlled laparoscopic versus open appendectomy, the studies showed a wound infection rate of 7.2 percent for open appendectomy versus open appendectomy [16].

For the present study, the return to daily life and work (days) for open appendectomy is 27.2. In other research, this decrease in hospital duration has a direct impact on expenditure while LA cost exceeds OA; the difference between the total expenditures of the two treatments is reduced by lower time spent at the hospital. Medical costs are below OA, even if the cost is reduced [17]

In comparison with opened appendectomy, also recent retrenching cohort studies or chart examinations found a shorter hospital stay in laparoscopic appendectomy. The period of return to normal operations in open appendectomy ranged from 7-25 days (mean 14.8 days) and in laparoscopic appendectomy from 7-15 days (mean 9.8 days) [18]

\section{Conclusion:}

Laparoscopic appendectomy is a safe, simple, and efficient technique for the treatment of appendicitis in experienced hands, the procedure gives better patient cosmetic results and fewer postoperative complications, decreased pain following surgery, a short hospitalization, and an early return to work. Laparoscopic appendectomy should be recommended for acute appendicitis as an effective and safe procedure.

\section{References}

1- McBURNEY C.: IV: The incision made in the abdominal wall in cases of appendicitis, with a description of a new method of operating. Annual Surgery, 20: 38-43, 1894.

2- WEI B., QI C.L., CHEN T.F., ZHENG Z.H., HUANG J.L., HU B.G. and WEI H.B.: Laparoscopic versus open appendectomy for acute appendicitis: A metaanalysis. Surgery Endoscopid., 25: 1199-208, 2011.

3- MINUTOLO V., LICCIARDELlO A., Di STEFANO B., ARENA M., ARENA G. and ANTONACCI V.: Outcomes and cost analysis of laparoscopic versus open appendectomy for treatment of acute appendicitis: 4 years of experience in a district hospital. BMC Surg., 14-14, 2014. 
4- WERKGARTNER G., CERWENKA H., EL SHABRAWI A., BACHER H., HAUSER H., MISCHINGER H.J., et al.: Laparoscopic versus open appendectomy for complicated appendicitis in high risk patients. Int. J. Colorectal. Dis., 30: 397401, 2015.

5- TAGUCHI Y., KOMATSU S., SAKAMOTO E., NORIMIZU S., SHINGU Y. and HASEGAWA H.: Laparoscopic versus open surgery for complicated appendicitis in adults a randomized controlled trial Surg. Endosc., 2016.

6- LI P., HAN Y., YANG Y., GUO H., HAO F. and TANG Y.: Retrospective review of laparoscopic versus open surgery in the treatment of appendiceal abscess in pediatric patients Laparoscopic versus open surgery for appendiceal abscess. Medicine, 96: 30, 2017.

7- SEMM K.: Endoscopic appendectomy. Endoscopy, 15: 59-64, 1983.

8- BATAJOO H. and HAZRA N.K.: Laparoscopic versus Open appendectomy in Acute Appendicitis. Nepal. Health Council Journal, 10 (22): 239-42, 2015.

9- PRADHAN S., SHAKYA Y., BATAJOO H., MALLA B., JOSHI H., THAPA L. and MAKAJU R.: Laparoscopic versus open appendectomy a prospective comparative study. Journal of Society of Surgeons of Nepal., 18 (2), 2015.

10- WANG D., DONG T., SHAO Y., GU T., XU Y. and JIANG Y.: Laparoscopy versus open appendectomy for elderly patients, a meta-analysis and systematic review. Wang BMC Surgery, 19: 54, 2019.

11- JEN H. and SHEW S.: Laparoscopic Versus Open Appendectomy in Children: Outcomes Comparison Based on a Statewide Analysis. Journal of Surgical Research, 161: 13-7, 2010.
12- BIONDI A., Di STEFANO C., FERRARA F., BELLIA2 A., VACANTE3 M. and PIAZZA2 L.: Laparoscopic versus open appendectomy: A retrospective cohort study assessing outcomes and cost-effectiveness. World J. Emerg. Surg., 11: 44, 2016.

13- JEON B., KIM H., JUNG K., KIM S., PARK J., KIM K., KIM D. and LEE S.: Prolonged operative time in laparoscopic appendectomy Predictive factors and outcomes. International Journal of Surgery, (36): 225-32, 2016.

14- TAKAMI T., YAMAGUCHI T., YOSHITAKE H., HATANO K., KATAOKA N., TOMITA M. and MAKIMOTO S.: A clinical comparison of laparoscopic versus open appendectomy for the treatment of complicated appendicitis. Historical cohort study European Journal of Trauma and Emergency Surgery, 2019.

15- SWANK H.A., ESHUIS E.J. and VAN BERGE HENEGOUWEN M.I.: Short-and Long-Term Results of Open Versus Laparoscopic Appendectomy. World Journal of Surgery, 35: 1221, 2011.

16- HASSAN A.M.: Laparoscopic versus open appendectomy in upper egypt: A prospective, randomized double blind study. Al-Azhar Asuitmedical Journal, 13, 2015.

17- NASSIR A., KASHHA A., ALTRABOLSI A., GHANNAM A., SIND O. and ALZIMAITY A.: Laparoscopic Appendectomy between the Advantages and Complications. A Cross Section Study in Saudi Arabia The Egyptian Journal of Hospital Medicine, 67 (2): 660-5, 2017.

18- ZOSIMAS D., LYKOUDIS P.M., PILAVAS A., BURKE J., LEUNG P., STRANO G. and SHATKAR V.: Open versus laparoscopic appendicectomy in acute appendicitis: Results of adistrictgeneral hospital S. Afr. J. Surg., 56, 2018 . 


\section{هل إستئصال الزائدة الدودية بالمنظاريعلو عن الفتح الجراحى?}

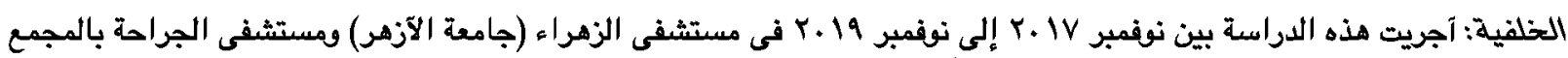

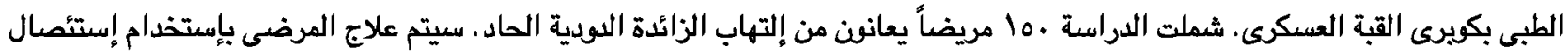
الزائدة الدودية بالمنظار والتقليدية المفتوحة.

الهدف من البحث: هو تقييم ما إذا كان إستئصال الزائدة اللودية بالمنظار (LA) متفقق على إستئصال الزائدة الودية التقليدى بالطريقة

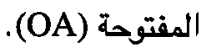

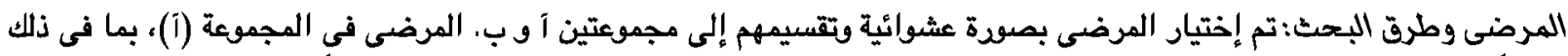

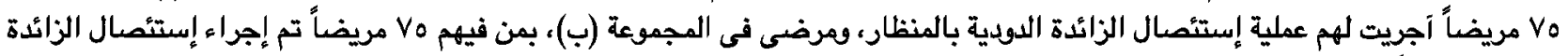

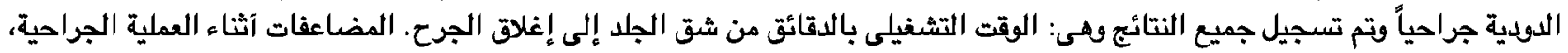

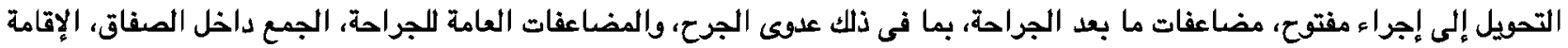
فى المستشفى بعد الجراحة، الآلم ما بعد إجراء العملية الجراحية فى اليوم الآلط.

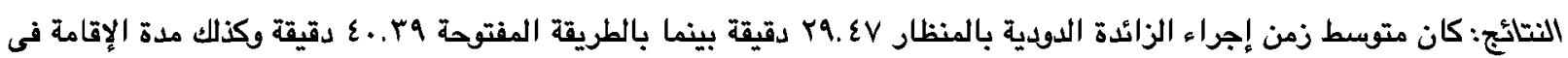

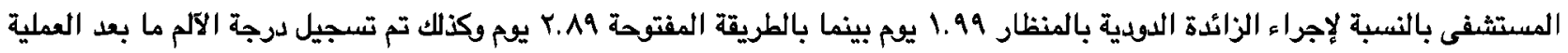

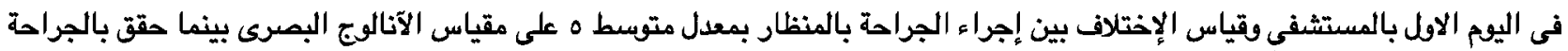

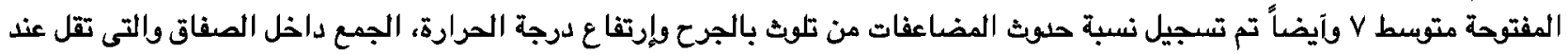

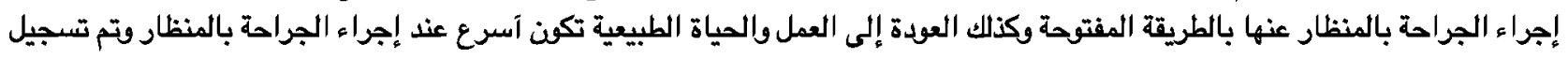
تآثير إجراء الجراحة بالطريقة المفتوحة على تآخر العودة إلى العمل والمياة الطبيعية العية العياة الإستتاج: نستطيع آن نخلص آن عملية إستئصال الزائدة الدودية بالمنظار لها الآفضلية وتحقيق نتائج آفضل عند مقارنتها بالفتح الجراحى فى حال توفر الإمكانات والجراح المتمرس. 